\title{
THE THEOLOGICAL PORTRAYAL OF FORGIVENESS IN ZECHARIAH 1-8
}

\author{
Danie F O'Kennedy \\ Department of Old and New Testament \\ Stellenbosch University
}

\begin{abstract}
Zechariah 1-8 has an optimistic undertone and describes Yahweh's love for the post-exilic community in Jerusalem. At least three passages refer directly to forgiveness: Zech 1:16 - "Therefore, thus says the Lord, I have returned to Jerusalem with compassion"; 3:4 - "See I have taken your guilt/sin away from you, and there will be festal clothing for you"; and 3:9 - "... and I will remove the guilt of this land in a single day". All these references belong to the second section of Proto-Zechariah (1:7-6:15) that contains seven (or eight) visions interspersed with oracles. Two of the prominent forgiveness references are found in the vision of the high priest Joshua (3:1-10). This vision is different from the others and some scholars believe that 3:1-7 (8-10) may be part of a later addition or exclude it from the sequel numbering of the visions (Jeremias, Meyers \& Meyers, Petersen, Reventlow, Willi-Plein, et al). This article discusses the portrayal of forgiveness in Zechariah 1-8 offering a few possible answers to the following questions: (1) What is the content of forgiveness in Zechariah 1-8? (2) Were the forgiveness references later additions? (3) Does 3:1-10 describe a ritual of forgiveness? (4) Was the rebuilding of the temple a sign or symbol of forgiveness? (5) Was forgiveness a central theme for the post-exilic community in Jerusalem?
\end{abstract}

\section{Introductory remarks}

Most modern scholars accept the fact that the book of Zechariah can be divided in two (1-8, 9-11) or three (1-8; 9-11; 12-14) distinct units (Willi-Plein 1998:540). The books of Haggai and Zechariah 1-8 (or Proto-Zechariah or First-Zechariah) are often discussed together but scholars have divergent opinions concerning the composition of these books. ${ }^{2}$ These Biblical books ${ }^{3}$ can be discussed as a whole (and as part of the Book of the Twelve) but it is also important to make a distinction. This article acknowledges the similarities and relationship between Haggai and Zechariah 1-8 but will focus on Zechariah 1-8. The main reason is due to the lack of forgiveness references in the book of Haggai (cf E).

1. A shortened version of this article was delivered as a paper at the SBL International Meeting in Berlin (19-22 July 2002). This article is the result of research done at the University of Hamburg under the guidance of Proff Ina Willi-Plein and Stefan Timm. The author wants to express his gratitude towards the University of Hamburg and of Stellenbosch University for their financial support.

2. There is a definitive relationship between these two books and the respective prophets. The prophet Zechariah was a contemporary of Haggai and the two are named in Ezra 5:1 as the prophets who urged the rebuilding of the temple in $520 \mathrm{BCE}$. There are different opinions on the relationship between the books Haggai and Zechariah 1-8: (a) Some scholars think that these two books were originally a single book edited by the same final redactor or composer (Meyers \& Meyers 1987:xliv-xlviii; Sykes 1997:124), (b) Others believe that Zech 1-8 was a response to Haggai and therefore written by different editors in different times (Petersen 1985:124125).

3. Some commentaries discuss the books Hag, Zech and Mal together. One can say that there is closer relationship between Hag and Zech 1-8, and between Zech 9-14 and Mal (Willi-Plein 1998:540). 
Zechariah 1-8 has an optimistic undertone and describes Yahweh's love for the postexilic community in Jerusalem. The neglected concept of forgiveness ${ }^{4}$ forms part of this optimistic undertone and at least three passages refer directly to forgiveness (Zech 1:16; $3: 4,9)$; therefore this article will focus on these and other related passages. The discussion will offer a few possible answers to the following questions: (1) What is the content of forgiveness in Zechariah 1-8? (2) Were the forgiveness references later additions? (3) Does 3:1-10 describe a ritual of forgiveness? (4) Was the rebuilding of the temple a sign or symbol of forgiveness? (5) Was forgiveness a central theme for the post-exilic community?

\section{Historical background to Zechariah 1-8}

The books of Zechariah 1-8 and Haggai originated in the post-exilic community of Jerusalem. ${ }^{5}$ It is difficult to construct the exact historical setting but the biblical text and non-biblical material provide us with a few clues. When the Babylonian Nebuchadnezzar seized Jerusalem in $586 \mathrm{BCE}$, he broke down the wall of the city in places and burned down the temple along with other important buildings. It is not clear what the extent of this damage was but it seems as if worship continued at the altar of the temple in the exilic period. When Cyrus issued his decree in $538 \mathrm{BCE}$ allowing the exiles to return to Jerusalem he made the Judahite Shesbazzar the first governor and in charge of the building project. Although Ezra 5:16 says that Shesbazzar laid the foundations of the temple it is difficult to tell what his role was and what he did. The book of Ezra does not mention his name again and the books of Haggai and Zechariah refers to the role of Zerubbabel in die temple building process (Redditt 1995:4-10). What we know is that Haggai instructed the people in $520 \mathrm{BCE}$ to start with the temple building and that it was completed in the sixth year of Darius (515 BCE).

The texts of Haggai and Proto-Zechariah place their historical setting in the second year of Darius, the Persian king (cf Hag 1:1; Zech 1:1). Three factors regarding the early years of Darius (522-486 BCE) are significant for the time of the prophet Zechariah. (1) There were widespread revolts at the beginning of his reign and he was confronted with political and military obstacles. In Babylonian documents Darius claims that he fought nineteen battles and took nine kings captive in a single year (OP 131, §52). ${ }^{6}$ The turmoil in Babylon may have been an encouragement to some Jewish exiles to return to Palestine; (2) The political and military struggles of Darius (522-519 BCE) were followed by his efforts to provide the Persian empire with an effective administrative system. According to Herodotus, Darius was remembered for his administrative and trading skills. Darius organized his Persian empire in different "protectorates" or satrapies which included smaller units or provinces. Judah, now called Yehud in Aramaic, was part of the fifth satrapy called Abar Nahara (Beyond the river). Darius's specific interest in detail administration throughout the empire, may have reflected in his concern for the Jerusalem cult. It is also possible that the Persian encouragement to codify laws in the different

4. The author has a broad working definition of forgiveness: 'Forgiveness is a deliberate act of God's grace towards the sinner/s which changes the status of sin or its consequences; or an altered disposition of God towards the punishment of sin or towards the sinner (cf O'Kennedy 1997:105).

5. Scholars use different names referring to this community and its people: Jews; the province Yehud; Israelites; Jerusalem based community; post-exilic community in Jerusalem; people of God/Yahweh; etc. Different names will be used in this article but it all refers to the Jerusalem based post-exilic community that lived in the Persian province Yehud.

6. Kent, RG 1950. Old Persian: Grammar, Texts, Lexicon. New Haven: American Oriental Society. 
provinces may have been an impetus for the forming of the books Haggai and Zechariah (Miller \& Hayes 1986:450-456; Meyers \& Meyers 1987:xxxi-xxxvii).

The specific circumstances in the Jerusalem community were difficult to describe. We can accept that the post-exilic economy was not strong and bad crops and possible reluctance of the people had impeded progress on the rebuilding of the temple. But the success of Haggai's and Zechariah's ministries helped to turn around a terrible situation. We can probably say that Zechariah experienced a more positive situation than Haggai. Society had already started to transform. Progress on the rebuilding of the temple served as a marker for the beginning of a new era (cf Zech 3:9 and 4:19) (Meyers 1987:510-513). This optimistic undertone serves as a background to the understanding of the forgiveness references.

\section{Structure of Zechariah 1-8}

There are some studies supporting a complex redactional process of the first eight chapters or the visions (cf Beuken 1967:84-183; 230-336). It is not the intention of this article to discuss these redactional processes in detail. I merely want to state the broader structure of Proto-Zechariah. Most modern scholars agree that Proto-Zechariah falls into three distinct literary units (Achtemeier 1986: 109; Meyers \& Meyers 1992:1062-1063; Willi-Plein 1998:540-541; Redditt 2000:1412-1413; et al). ${ }^{7}$

- 1:1-6: Summons to repentance

- 1:7-6:15: Seven (or eight visions) interspersed with oracles

- 7:1-8:23: Features of the time of salvation

These three literary units may be divided into further sections. ${ }^{8}$ The three prominent forgiveness references $(1: 16 ; 3: 4 \text { and } 9)^{9}$ appear in the first and second units. We shall therefore discuss these references in detail.

\section{Forgiveness references in Zechariah 1-8}

\subsection{Zechariah 1:7-17 (1:16)}

Text and translation of Zechariah 1:16 ${ }^{10}$

"Therefore, thus says Yahweh, I have returned to Jerusalem with compassion, my house shall be built in it, says Yahweh of hosts, and the measuring line shall be stretched out over Jerusalem.”

7. Smith (1984:181) believes that the symbolic crowning of Joshua (6:9-15) forms a separate unit or section.

8. Cf commentaries on Zechariah for division.

9. We refer to the prominent forgiveness passages in proto-Zechariah. The question remains: Do we have other forgiveness passages? Zech 1:12 refers indirectly to forgiveness when the angel of the Lord asks the following question: 'O Lord of hosts, how long will you withhold mercy from Jerusalem and the cities of Judah, with which you have been angry these seventy years?' One can pose the question whether wrath against the nations means love and forgiveness towards Israel. Israel was punished by means of other nations because of her sins. Does the punishment of other nations mean that Yahweh forgave his people? In Zechariah 4:7 one reads the חן חן (Grace, grace to it). This verse predicts that when Zerubbabel completed the rebuilding of the temple, the people would shout 'Grace, grace to it'. In some instances the Hebrew term

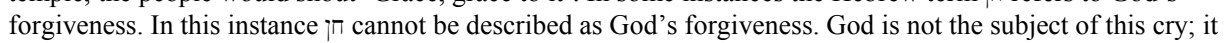
rather conveys the meaning of favour, perhaps even beauty. The people could not withstand their joy in the beauty of the restored temple.

10. Own translations will be made of the 3 forgiveness references. Other citations are taken from the NRSV of the Bible unless mentioned otherwise. 
The perfectum verb שבת can be translated as a so-called perfectum propheticum (I shall return) or as a past tense predicate (I have returned). Many text traditions (LXX, Targum, Vulgate, Peshitta) translate it into the future tense. This may be possible in the light of the imperfectum being used in the next sentence (my house shall be built in it) and in Zechariah 8:3 we have the future use of the verb. However, two reasons may be given supporting the above translation: (1) The MT has a perfect verb; (2) The first vision and literary context suggests that Yahweh has already returned to Jerusalem since the temple project started (cf 1:1,7). The text may also be intentionally ambiguous (cf Petersen 1985:156). However, whether turning toward or returning, the text emphasizes that Yahweh acts with compassion.

שוב The verb (turn, return, repent) occurs twice in Zechariah 1:3 and once in 1:6. We can say that the use of שוב completes the two sets of counterpoised returnings found in the first chapter of Zechariah: People return/repent (v 3 and 6) - Yahweh returns (v 3 and 16) (Meyers \& Meyers 1987:123).

One does not find 0 the most important Hebrew term for divine forgiveness in this passage. However, the Hebrew term רחמים (compassion) conveys the meaning of forgiveness when it is used with Yahweh as subject (Kselman 1992:832-833).

\section{Literary context, composition and structure}

Verse 16 is part of the first vision of Zechariah, one of the seven (or eight) ${ }^{11}$ visions stretching from 1:7-6:8. The first vision portrays a man riding a red horse with horses of other colours behind him. When he asked the meaning of the vision he was told that they had been patrolling the earth. Verse 12 introduces the following question posed by the messenger or angel: "O Yahweh of hosts, how long will you withhold mercy (תרחם) from Jerusalem and the cities of Judah, with which you have been angry these seventy years?" This question was answered by "gracious and comforting words" stating that Yahweh was very jealous on Jerusalem and angry with the nations. After verse 16 the passage closes with the proclamation that the cities will overflow with prosperity.

Zechariah 1:14-17 describes an oracle, ${ }^{12}$ which some scholars regard as secondary. However, we believe that verses 14-17 form an integral part of the first vision. This close connection is supported by grammatical and stylistic features. Verse 13 would make a suitable ending to this vision but would leave the question of the interpreting angel unanswered. Verses 14-17 report the content of the gracious and comforting words (Redditt 1995:51). Some scholars believe that verse 16 and 17 form part of a later addition (cf Meyers \& Meyers 1987:122) but there is not enough evidence supporting this viewpoint. Verse 16 is introduced by the particle לכן (therefore) indicating a connection between this verse and the previous verses, and the language of Yahweh's "return" relates to a theme that was prominent in the beginning of the chapter. The occurrence of the Hebrew root in both verses 12 and 16 provides further support for the unity of the this passage and suggests common authorship for Zechariah 1:7-17.

Scholars have divergent views regarding the division of the first vision and oracle. ${ }^{13} \mathrm{We}$ support the idea that 1:7-17 forms a literary unit and propose the following structure:

11. Cf detailed discussion of visions in $\mathrm{D}: 2 \mathrm{~b}$.

12. Meyers \& Meyers (1987:132-134) believe that we have 3 oracles here: vv 14-15; v 16; and v 17.

13. Zech 1:7-15; 16-17 (Smith 1984:188-189); Zech 1:7, 8-15, 16-17 (Reventlow 1993:39-44); 1:7, 8-11, 12-15 (Delkurt 2000:20). 
(A) Superscription to the visions

(B) Vision

- Description of vision

8

- Interpreting of vision

- The horsemen's report to the angel

11

- Angel's complaint to Yahweh

12

- Yahweh's reaction: gracious and comforting words

13

(C) Interpreting angel's speech to the prophet:

(D) Commission to proclaim

Yahweh's message

Jealous of Jerusalem and angry with the nations 14-15

Return to Jerusalem with compassion;

Temple and city will be rebuilt 16

Prosperity and the re-election of Jerusalem 17

\section{Theological dimension of forgiveness}

The first vision concludes with a message of salvation and forgiveness. In fact this positive trend starts in verse 12 with the question concerning the withholding of Yahweh's mercy (תרחם) from Jerusalem. In the first vision two Hebrew terms describing the love, comfort and forgiveness of Yahweh occur: רחמים (compassion; v 16) and the stem (comfort; vv 13 and 17).

In Zechariah 1:3 we read the following "Return to me, says Yahweh of hosts and I will return to you, says Yahweh of hosts". Zechariah 1:16 does not portray the same precondition of repentance before Yahweh will return. According to verse 16 Yahweh's return will be an unconditional return; a return because there is compassion (רחמם) in His heart. Yahweh's compassion and forgiveness will not merely be empty words. He will return to his people and to the city Jerusalem to build His house (or temple) as a symbol of His presence, hope and forgiveness. We can say that Zechariah 1:7-17 builds up to a climax: from the description of the vision to the proclaiming of Yahweh's gracious prosperity and re-election of Jerusalem.

Yahweh "proves" his forgiveness by the rebuilding of the temple. Actually his forgiveness comprises more than the temple. The phrase "and the measuring line shall be stretched out over Jerusalem" (v 16b) signifies that the city too will be rebuilt. Forgiveness forms the starting point of a new community and can even lead to socio-economic stability and prosperity ( $\mathrm{cf} v 17)$.

\subsection{Zechariah 3:1-10 (4 and 9)}

\section{a. Text and translation}

\section{Zachariah 3:4}

"And he (the angel) answered and said to those who were standing before him: "Take off his filthy clothes." And he (the angel) said to him (Joshua): "See I have taken your guilt away from you, and there will be festal clothing for you"

According to the MT verse 4 starts with the word ויען ויאמר (and he answered and said). Although we prefer the more literal translation this phrase could also be translated into "and he spoke out" or merely "and he said". The direct literary context assumes that the third person singular is "the angel"; therefore some Bibles translate it accordingly (cf NRSV; NIV; Peshitta). 
It is interesting to note that the Hebrew words בגדים זואים (dirty clothes) is used and not the cultic term טמכא (unclean). Some scholars translate it with "unclean" or "unreine Gewänder" but the words of the Hebrew text do not have the same cultic connotation. It could be that the "dirty clothes" symbolize something of the socio-economic situation of the post-exilic community at that time. The high priest was wearing old and dirty clothes, because there were no good clothes available. However, this hypothesis seems to be unlikely $(\mathrm{cf} 2 \mathrm{e})$.

The textual-apparatus of BHS mentions the fact that the phrase "and he said to him: 'See I have taken your guilt away'" be transposed after verse 5 . A further suggestion in line

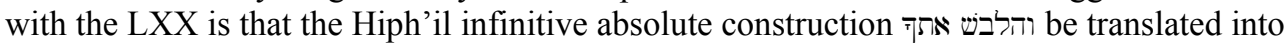
the imperative plural with אתו (to him); ór with Hiph'il imperfectum $3^{\text {rd }}$ person plural. Although the use of the infinitive absolute seems a bit unusual the MT can be supported, because it continues the intention of the clause in the previous verse (I have removed or I have taken away) (cf Meyers \& Meyers 1987:190; Hanhart 1998:170). It is difficult to translate this infinitive absolute and there are two German translations that portray the meaning of the MT the best: "man kleide dich in Prachtgewänder" (Willi-Plein 2002:54) or "und nun sollst du mit Festgewändern bekleidet werden” (Hanhart 1998:167).

The word מחלצות is difficult to translate, because it only occurs here and in Isaiah 3:22, where it is included in a list of finery that the ladies of Jerusalem possess. Scholars and Bible translations have different translations: "rich garments" (NIV); "festal clothes or apparel" (NRSV; Reventlow 1993:51; Hanhart 1998:167); "pure vestments" (Meyers \& Meyers 1987:178) ${ }^{14}$; "Prachtgewänder" (Willi-Plein 2002:54). Although it is difficult to translate, the whole meaning of this term points to the contrast with the "filthy clothes".

The Jerusalem Bible modified verse $4 \mathrm{~b}$ so that the declaration of cleansing takes place after his clothes have been changed and the turban placed upon his head. This rearrangement of verses 4 and 5 to make the visions smooth and logic is unwise (Harrelson 1992:116).

\section{Zechariah 3:9}

"For/yes, see the stone that I have set before Joshua, on a single stone with seven facets, I will engrave its inscription, says Yahweh of hosts ${ }^{15}$ and I will remove the guilt of this land in a single day"

This verse has no difficult translation problems. Some scholars find it difficult to translate the words כי כנה in the beginning of the verse, but it does not have any influence on the meaning of the verse. The text-critical apparatus of BHS suggests that the words "before Joshua" may be read "before you" or "before him". It is interesting to note that the same word for sin or guilt (עון) is being used in both forgiveness references but the verbs differ. The term (v 5) conveys the meaning "take away" or "let it go away", but the word (v 9 and Mic 2:3) has a stronger meaning (e g remove).

b. Composition of Zechariah 3 within the visions (1:17-6:15)

Scholars have divergent opinions concerning the composition and status of Zechariah 3. One can summarize these different viewpoints as follows: (1) Scholars that regard Zechariah 3 as one of the eight visions although they differ over the redactional process or

14. Meyers \& Meyers (1987:190) reckons that root ${ }^{4}$ could stem from certain Arabic and Assyrian words and therefore translate it with pure vestments. Their hypothesis is still uncertain.

15. Willi-Plein (2002:59) chooses to transliterate the Hebrew phrase (YHWH Zebaot) instead of translating it. She believes that no translation can portray the true meaning of this Hebrew phrase. 
structure (Beuken 1967:282-316; Petersen 1985:187-188; Le Roux 1987:302; Hanshart 1998:205-213; Delkurt 2000:141-194; Floyd 2000:326-327; Redditt ${ }^{16}$ 2000:1412; et al). Many of these scholars believe that this vision comes from Zechariah himself and forms part of the earliest material in Proto-Zechariah; (2) Scholars who believe that there are only seven visions and that this chapter may be a later addition (cf Reventlow 1993:52). ${ }^{17}$ This later addition descended from the prophet Zechariah or from another redactor; (3) Scholars who acknowledge Zechariah 3 as a vision but exclude it from the sequel numbering of the visions; therefore they refer to seven visions and an extra prophetic vision (Jeremias ${ }^{18}$ 1977:201-203; Meyers \& Meyers 1992:1063; Willi-Plein 1998:540).

Why do some scholars exclude Zechariah 3 from the rest of the visions or find it problematic? Several motivations ${ }^{19}$ may support their viewpoint: (1) The third chapter starts with the Hiph'il form of the verb (ויראני) in contrast to the introductions of the other visions which use a Qal form with the prophet as subject. This means that someone shows Zechariah the vision whereas elsewhere he sees it; (2) The investiture that is portrayed deals with real historical people (e g Joshua) and objects, and not with elaborate imaginary characters or situations; (3) This is the only vision where Satan is mentioned; (4) The prophet is cast in a double role: he is witness to the scenes of the vision and an actor in them; (5) It lacks the interpreting angel; Yahweh appears to be a direct actor in the drama; (6) The vision moves through a large cast of characters within a few verses (Jeremias 1977:201-203, Meyers \& Meyers 1987:179; VanderKam 1991:554; Redditt 1995:40).

We have mentioned the differences between Zechariah 3 and the other visions. Despite these differences one can list five reasons supporting the viewpoint that this vision has a definite relationship with the other seven visions: (1) The opening word ויראני (hed me) continues a structure found in some of the other visions (cf Zech 2:1, 3, 5 [1:18, 20 and 2:1]); therefore the Hebrew text labels Zechariah 3 as a vision; (2) This vision compares to the other heavenly meetings $(1: 7-17 ; 6: 1-8)$; (3) The angel speaks a clear explanatory word $(3: 4 b)$; (4) The high priest Joshua stands in the center and plays an important role in the next vision as well (4:1-14); (5) The words of verse 7 explain the previous events (Jeremias 1977:201; Meyers and Meyers (1987:179).

We have mentioned a few contact points with the other visions. On the other hand, one can argue that this is an unique vision that was inserted in a specific place in the Hebrew text. Zechariah or any other redactor could have written this unique vision to emphasize a specific viewpoint. The author acknowledges Zechariah 3 as a true vision that forms an integral part of the seven visions placed in the center together with the fourth vision. The author excludes Zechariah 3 from the sequel numbering of the visions; therefore referring to seven visions and an extra prophetic vision.

16. It seems as if Redditt $(1995: 41,62 ; 2000: 1412)$ has two divergent viewpoints. In his discussion of the structure in his NCB Commentary (1995:41) he says that 3:1-10 does not belong to the original sequence of the visions, but in his article in the Eerdmans Dictionary of the Bible (2000:1412) he refers to 3:1-10 as the fourth vision. We accept his latest article as his current viewpoint.

17. Reventlow (1993:52) believes that it does not act as a vision but rather as a 'visionär geschaute Vorgänge im himmlischen Thronrat Jahwes’ that could be compared with Isa 6, 1 Kgs 22:19-23, Job 1:6-12 and 2:1-6.

18. The exact viewpoint of Jeremias is difficult to know. Sometimes he refers to $3: 1-7$ as the fourth vision, but he also expresses his uncertainty (1977:6, 201-203).

19. Delkurt (2000:147) lines up with Jeremias and Meyers \& Meyers and provides 17 possible reasons why Zechariah 3:1-7 does not form part of the seven visions. We have only concentrated on the most important reasons. 
c. Structure of Zechariah 3

Scholars have divergent opinions concerning the structure of Zechariah 3. Many scholars see verses 8-10 as a supplementary oracle (Eichrodt 1957:509; Le Roux 1987:303; Meyers \& Meyers 1987:222; Reventlow 1993:54; et al). Redditt's (1995:62-63) viewpoint differs from the previous mentioned scholars. The first five verses has the divine council as its setting, where Joshua the high priest was cleansed. Zechariah 3:6-7 and 9 fits perfectly into this scene. According to Redditt verses 8 and 10 sound messianic. The title צמח (the branch) would be more appropriate for Zerubbabel than for Joshua and these verses seemed to interrupt more than to interpret. Redditt therefore treats verses 8 and 10 as additions. Petersen (1985:202) comes to the conclusion that the vision report originally consisted of 3:1-5 and that there were three additions: verses 6-7, 9 and verses 8 and 10 .

From a "forgiveness" perspective there seems to be some relationship between verse 9 and verses 1-7. Verse 4 refers to forgiveness (עבר און) as well as verse 9 (מוש און). The same word for guilt or sin is used, although the verbs are not the same. One can argue that the forgiveness in verse 4 deals with the individual Joshua, while verse 9 deals with the land (א). On the other hand the high priest Joshua was an important representative of the land. Therefore, from a "forgiveness" perspective we can agree with Redditt that verse 9 must be included or one can argue that verses 1-10 must form a unit. There is a possibility that the oracles in verses 8-10 are later additions, but one must not ignore the relationship between these verses. Visions in the Old Testament frequently included oracles (cf Long 1971:359364). In the visions of Zechariah the oracles are incorporated in such a way that one could not separate the one from the other; however, it seems as if some may appear to be selfcontained units (cf 2:10-17 [2:6-13]).

What is the structure and division of Zechariah 3 Floyd (2000:371) proposes an interesting viewpoint concerning the division of chapter 3 . He argues that this chapter be divided into three main acts: (1) Dismissal of the charge against Joshua (3:1-2); (2) Purification of Joshua (3:3-5a); (3) Joshua's commission to head the restored temple cult (3:5b-10). The structure of Floyd emphasizes the purification of Joshua as the center or core of this chapter.

In the light of the abovementioned structure we suggest the following:

A. Dismissal of the charge against Joshua

1. Introductory description of the scene

2. Speech of Yahweh rebuking Satan

B. Purification of Joshua

1. Introductory description of scene

2. Cleansing and forgiveness by Yahweh via messenger

3. Compliance of background figures with the prophet's directive $3: 5 \mathrm{a}$

C. Joshua's commission to head the restored temple cult

1. Pre-conditions for Joshua's task

2. Divine promises for Joshua and friends:

- Coming of servant, the branch

- Stone will be engraved

- Forgiveness will be granted to the whole land

- Consequences for the people 
We have accepted Floyd's broader structure but differs from his more detailed structure. The chapter starts in the A section with Yahweh showing the prophet a certain vision. In the $\mathrm{B}$ section the angel is the speaker. This section may be labeled the core or center of this whole passage. In verse 6 the text portrays that the angel proclaims what Yahweh has spoken and the speaker never changes till the end of the chapter; therefore we do not agree with some scholars who separate verses 8-10 from verses 6-7. The expression "Yahweh of hosts" is frequently used in these verses (vv 7, 9-10). There is also a direct relationship between verse 9 and verse 10 through the expression ביום (day).

\section{d. Sitz im Leben - ritual of forgiveness?}

Most of the recent commentators (Hanhart, Meyers \& Meyers, Petersen, Redditt, Reventlow, et al) agree that the historical context of this passage is the beginning of Judah's restoration under the Persians in the last part of the sixth century BCE. The scene envisioned by the prophet is the heavenly council with the messenger or angel as spokesperson. One can speculate over the intention of this specific vision. In the context of Darius's reorganization of the Persian Empire it was crucial for the returning exiles to have a form of self-government. The vision serves to legitimate the role of the high priest. The high priest receives a juridical function that formerly pertained to the prophets and a divinatory function formerly executed by the prophets. He will fulfill this role until the time when a descendant of David could resume the role of king (3:8).

Do we have an existing cult during the time of the vision? The returned exiles wanted to restore the cult and it is possible that an altar was constructed in sacred places even before the reconstruction of the temple (Ezra 3:1-7; Hag 1:1-15a). Questions emerging about the legitimacy of the priests were asked (Ezra 2:61-63). The priests first had to perform cultic rituals for themselves before they could take part in atonement rituals for the people (Lev 9:7-21) (Floyd 2000:377).

The real issue in this article is: Does this passage refer to a ritual of forgiveness? According to the MT one cannot unequivocally speak of a ritual of forgiveness. ${ }^{20}$

- There is no typical description of a cultic ritual like in Leviticus 4 and 5 (cf also Lev 19:22; Num 15:25, 26 and 28). According to Leviticus 4 and 5 there was a ritual of forgiveness where the priest performed the ritual of atonement on behalf of Yahweh and the forgiveness points to the result or consequence of the whole ritual (cf Lev 4:31; $5: 10,18)$. The ritual consists of offerings, the symbol of blood, confession of sins, et cetera (O’Kennedy 1999:101-105).

- There is also a scarcity of cultic words in Zechariah 3. The description of filthy clothes

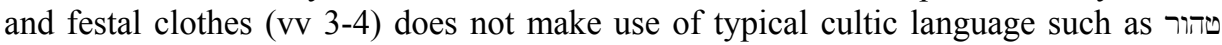
(clean) and טמא (unclean). The Hebrew term for sin commonly used with cultic rituals (cf Lev 4:26, 28) does not appear in this text. The Hebrew terms conveying the concepts of forgiveness are also not typical for a cultic context. For a typically cultic context one would have expected terms like כפר (atone, expiate) or (forgive).

- There is no reference to an earthly place where this ritual could have taken place. The MT sketches the context of the heavenly council.

20. Some German scholars use the word 'Entsühnen' instead of forgiveness. The word 'Entsühnen' is difficult to translate into English. It may be translated with words like 'to expiate, to atone for, to purify'. The German word 'Entsühnen' is probably not the correct word to use due to its merely cultic connotation. 
One must acknowledge that the description in verse 5 refers more to a cultic ritual. The cultic word טהור is used when the clean turban (ציף) is described. Petersen (1985:197-198) indicates that צניף is not the usual technical term for the high-priestly turban. The parallel Hebrew term מצנפת is more commonly used (cf Ex 28:4; 39:28; Lev 8:9, 16:4; etc).

In conclusion we must accept the fact that the textual evidence for a specific cultic ritual is weak ${ }^{21}$ but this does not mean that the forgiveness portrayed in this vision is not real forgiveness. Forgiveness is dependant on Yahweh's grace, not on a cultic ritual or a temple or specific magical words. Finally one may ask: Who "insisted" on the cleansing of Joshua? Was it Yahweh or the prophet or the post-exilic community? The MT of Zechariah 3:1 reads (and he showed me) but the subject is not specified and probably refers to Yahweh. We can only speculate whether there was other "pressure" besides that of Yahweh.

\section{e. Theological dimension of forgiveness ${ }^{22}$}

The question is why did the high priest Joshua needed forgiveness? Was it because of the strict nationalistic and exclusivist Yahwism practised by the post-exilic community? Or was it because he was not a son of exile? (cf Miller \& Hayes 1986:459). ${ }^{23}$ Perhaps the best way to describe it is not to focus on the individual Joshua, but on Joshua as the representative of the post-exilic community in the face of God. The guilt of Joshua refers to the guilt of the people of God. One can say that they already paid for their sins by being in exile (cf Isa 40:2) (Hanhart 1998:218).

Verse 4 refers to the removal of guilt or sin and therefore this can be seen as true שבר forgiveness. The text does not convey the fact that Yahweh is the subject of the verb but rather the messenger or angel of Yahweh. One can argue that Yahweh granted the forgiveness and merely sent his messenger to deliver this important message. The only role of a messenger is to deliver the message from the one who sends him; he does not deliver his own message. In that sense the messenger delivered the forgiveness proclaimed by Yahweh. Although the Hebrew text does not use Yahweh as the subject of the verb, one can therefore speak of true divine forgiveness. ${ }^{24}$

We have already argued that there is a lack of evidence pointing to a specific cultic ritual or cultic symbols. However, the symbols being depicted have a "strong" meaning and cannot be reduced. Joshua and the priests are described like a piece of wood (v 2) taken out of the fire of Yahweh's anger. The angels or deities of the divine council standing before Joshua is ordered to take off his filthy clothes and put new festal clothes on. If verse 2 referred to the exile, verse 3 implied that it was defiling. The change of clothes depicts a transition of an era of guilt and anger to a new era where Yahweh's love and forgiveness will be experienced (Le Roux 1987:302; Redditt 1995:64).

Verse 9 emphasizes the power of Yahweh's forgiveness. He can remove the guilt of the land in one day. In verse 4 the forgiveness is described in mild terms but in verse 9 we hear

21. Petersen (1984:198) says the following concerning the cultic character of Zechariah's visions: 'I contend that the case for the cultic character of these visions is weak. These visions focus even less on cultic matters than does Jeremiah's vision of the almond rod focus on ancient Near East horticulture (Jer I 11-12).'

22. According to Delkurt (2000:189) this vision reminds one of the vision in Isaiah 6. Delkurt believes that only these two texts describe the 'Ensühnung' of the individual in the framework of a vision.

23. Miller and Hayes (1986:459) reckons that the high priest Joshua seems to have been less exclusive and ritually demanding than the stricter Yahwists wished. According to Miller and Hayes the strict Yahwists were represented by Zerubbabel and the less strict Yahwists by Joshua.

24. To the author's knowledge this is the only reference in the Old Testament where the messenger or angel conveys a message of divine forgiveness. 
"stronger" Hebrew words: עבר (taken away, let it pass by) compares to מושר (remove in one day); forgiveness of the individual high priest (v 5) compares to forgiveness of the whole land (v 9).

The text conveys that the guilt will be removed in one day. Forgiveness could be sudden but in many instances it is the end of a process. In the Priestly literature (Lev 4 and 5) the granting of forgiveness was the end of the atonement ritual. One could probably say that in the history of the people of God the exile was part of this whole process.

We have referred to the contrast between the filthy and festal clothes. Zachariah 3:1-10 portrays another sharp contrast, namely the contrast between Satan as accuser and Yahweh as the One who is granting forgiveness. The passage starts in verses 1-2 with Satan accusing the high priest as representative of the people and concludes with Yahweh granting forgiveness and a new future.

The gift of a stone for Joshua implies a new phase in the history of the people of Yahweh (vv 8-9). A new time with the coming of the branch (Zerubbabel). Verse 10 also continues to say that the time of the exile as a time of guilt imprisonment is over (WilliPlein 2002:60). Forgiveness is more than a ritual or more than words. Divine forgiveness is something that every person can experience. That is why the description of the vine and the fig tree fits well into the forgiveness references. The people did not experience God's forgiveness during exile, but this vision gave them some hope.

Verse 7 can be interpreted as a pre-condition for forgiveness; however, the text shows no relationship between the "if" requirements in verse 7 and the granting of forgiveness in verse 9. The requirements in verse 7 have to do with the responsibility of Joshua as the high priest.

\section{Lack of forgiveness references in the Book of Haggai}

We have mentioned in the introduction that no reference to forgiveness could be found in the book of Haggai. Scholars agree that these books developed in the same time; therefore one can speculate on the reasons for this lack of references. One can offer four possible reasons or hypotheses: (1) The books of Haggai and Zechariah originated as one unit or book and the theme of forgiveness was discussed later in the book; (2) The concept of forgiveness was not so important to the prophet Haggai; (3) The building of the temple took all Haggai's attention so that he could not focus on the cleansing and forgiveness; (4) The people experienced forgiveness after the building of the temple started. In the beginning they only experienced the problems facing their everyday life.

It is difficult to choose one of these possible reasons due to a lack of evidence. Perhaps we can shed more light on the understanding of forgiveness in the post-exilic community. We know that more forgiveness passages originated in the exilic and post-exilic times compared to the pre-exilic times (Koch 1966:219-220; O'Kennedy 1994:107). People experienced God's forgiveness after they returned from exile. The exile was seen as part of God's anger and wrath but the return to Israel was seen as divine forgiveness. Haggai and Zechariah experienced the same circumstances; their theological emphasis was therefore a matter of choice. One cannot say that the temple played such a major role in the beginning that they "forgot" about God's forgiveness. The Bible portrays that there is a direct relationship between the temple in Jerusalem and the concept of forgiveness. 1 Kings 8:2253, one of the most prominent forgiveness passages in the Old Testament, has the dedication of the temple as its setting and the verb סלח occurs five times in this prayer of Solomon. We can speculate about the different hypotheses but the fact is that the book Haggai totally ignores the concept of forgiveness. 


\section{Summary and conclusion}

The above discussion has lead the author to make the following conclusions. In these conclusions we want to reply to the questions posed in the introduction.

(1) The content of forgiveness in Zechariah 1-8 portrays an interesting pattern. It seems as if the intensity of the forgiveness references rises: Yahweh returns with compassion to Jerusalem (1:16); Forgiveness proclaimed to Joshua, the high priest (3:4); Immediate forgiveness for the whole land (3:9). The first reference conveys something of Yahweh's "heart" that turned; the second reference focuses on the individual Joshua and Yahweh is merely taking away (עבר) his guilt; in the third reference the text depicts immediate removal (מוש) of the guilt of the whole land.

The forgiveness portrayed in Zechariah 1-8 is unconditional. The text does not mention any repentance or other pre-condition, before Yahweh will grant His forgiveness. Forgiveness is described as Yahweh's removal of the guilt (עון) of the people because He is a God of grace and compassion.

(2) One's view on the composition and structure of the visions may have a direct influence on the understanding of forgiveness. Some scholars believe that the prominent forgiveness passages $(1: 16,3: 4$ and 9) belong to the so-called prophetic oracles within the seven visions. We have argued that the visions and oracles form a unity and that one cannot separate the one from the other. We therefore believe that the forgiveness passages were an integral part of the book and most probably derived from Zechariah himself. The prophetic vision in Zechariah 3:1-10 together with the fourth vision can be regarded as the center or core of the seven visions. The prominence of cleansing and forgiveness in this passage (vv 4 and 9) may point to the significance of forgiveness for the post-exilic community.

(3) The text of Zechariah 3:1-10 and the other passages in Proto-Zechariah do not unequivocally speak of a ritual of forgiveness: (a) there is no typical description of a cultic ritual like in Leviticus 4 and 5; (b) there is also a scarcity of cultic words; (c) there is no reference to an earthly place where this ritual could have taken place. We must accept the fact that the textual evidence for a specific cultic ritual is weak but this does not mean that the forgiveness portrayed in this vision is not real forgiveness. Forgiveness is only dependant on Yahweh's grace, not on a cultic ritual or a temple or specific magical words.

(4) Zechariah 1-8 portrays that forgiveness is not merely empty words spoken by Yahweh. Yahweh "proves" His forgiveness in the following ways: letting the people return from exile $(1: 12,16)$; rebuilding of the temple, His house (1:16); rebuilding of Jerusalem (1:16); bringing of His servant, the branch (3:9); and peace and prosperity in the land $(1: 17 ; 3: 10)$.

(5) We cannot proclaim that forgiveness is the central theme in Zechariah 1-8; however, the text of Proto-Zechariah does not ignore or neglect the concept of forgiveness. Some people can say that the forgiveness is not real because it appears in the visions (1:176:15). They can argue that this did not actually happen, but were only visualized by the prophet. This may be true, but the fact is that these visions (and oracles) portray how the post-exilic community in Jerusalem experienced Yahweh their God. The Hebrew text of Zechariah 1-8 which originated in these circumstances provides us with enough evidence. The centrality of Zechariah 3:1-10, the prominent forgiveness passage, proves that forgiveness was an important theological theme for the post-exilic community in Jerusalem. 


\section{BIBLIOGRAPHY}

Achtemeier, E 1986. Nahum-Malachi. Atlanta: John Knox Press. (Interpretation.)

Beuken, WAM 1967. Haggai-Sacharja 1-8. Assen: Van Gorcum \& Comp.

Delkurt, H 2000. Sacharjas Nachgeschichte: Zur Aufnahme und Abwendlung prophetischer Tradition. Berlin: Walter de Gruyter. (BZAW 302.)

Eichrodt, W 1957. Vom Symbol zum Typos: Ein Beitrag zur Sacharja-exegese. TZ 13, 509-522.

Floyd, MH 2000. Minor prophets: Part 2. Grand Rapids: Eerdmans. (FOTL 22.)

Hanhart, R 1998. Dodekapropheton 7.1: Sacharja 1-8. Neukirchen-Vluyn: Neukirchener Verlag. (BK14/7.1.)

Harrelson, W 1982. The trial of the high priest Joshua: Zechariah 3. Eretz Israel 16, 116-124.

Jeremias, C 1977. Die Nachgesichte des Sacharja: Untersuchungen zu ihrer Stellung im Zusammenhang der Visionsberichte im Alten Testament und zu ihrem Bildmaterial. Göttingen: Vandenhoeck \& Ruprecht.

Kselman, J 1992. s v Forgiveness (OT). ABD 2, 831-833.

Koch, K 1966. Sühne und Sündenvergebung um die Wende von der exilischen zur nachexilischen Zeit. EvT 26, 217-239.

Le Roux, JH 1987. Die boek Sagaria, in Tweegesprek met God, Burden, JJ \& Prinsloo, WS (reds), 297-328. Kaapstad: Tafelberg Uitgewers. (Die literatuur van die Ou Testament 3.)

Long, BO 1971. Two question and answer schemata in the prophets. JBL 90, 129-139.

Meyers, EM 1987. The Persian period and the Judean restoration: From Zerubbabel to Nehemiah, in Miller, P D, Hanson, P D \& Mcbride, S D (eds), Ancient Israelite religion: Essays in honor of Frank Moore Cross, 509-521. Philadelphia: Fortress Press.

Meyers, C \& Meyers, EM 1987. Haggai, Zechariah 1-8. New York: Doubleday. (AB 25B.) 1992. s v Zechariah, Book of. $A B D$ 6, 1061-1065.

Miller, JM \& Hayes, JH 1986. A history of ancient Israel and Judah. Philadelphia: Westminster Press.

O’Kennedy, DF 1994. Die gebed om vergifnis. D Th dissertation, University of Stellenbosch. 1997. "It shall not be": Divine forgiveness in the intercessory prayers of Amos (Am 7:16). OTE 10/1, 92-108.

1999. "And it shall not be forgiven him/them": The concept of forgiveness in the Pentateuch. OTE 12/1, 94-113.

Petersen, DL 1984. Zechariah's visions: A theological perspective. VT 34/2, 195-206 1985. Haggai and Zechariah 1-8. London: SCM Press. (OTL.)

Redditt, PL 1995. Haggai, Zechariah, Malachi. Grand Rapids: Eerdmans. (NCB.) 2000. s v Zechariah, Book of. Eerdmans dictionary of the Bible, 1412-1413.

Reventlow, H G 1993. Die Propheten Haggai, Sacharja und Maleachi. Göttingen: Vandenhoeck \& Ruprecht. (ATD 25/2.

Smith, RL 1984. Micah-Malachi. Waco, Texas: Word Books. (WBC 32.)

VanderKam, JC 1991. Joshua the high priest and the interpretation of Zechariah 3. CBQ 53, 553-570.

Willi-Plein, I 1998. s v Sacharja/Sacharjabuch. TRE 29, 539-547. 2002. Haggai, Sacharja und Maleachi. Draft of commentary to be published in Züriher Bibelkommentare (ZBK). 